\title{
Commitment of Political Communication in the Mayor of Banda Aceh, Indonesia
}

\section{Zahari Nurdin}

Ph.D Student in State Islamic University of North Sumatera (UINSU), Medan, Indonesia Email: zahari.nurdin@gmail.com

\begin{abstract}
:
The development of political communication relies on multidisciplinary based on concepts in communication, political science, journalism, sociology, psychology, history, rhetoric, and others. This study deals with commitment of political communication in the mayor of Banda Aceh, Indonesia. Constructivism paradigm is used in this study to discuss the perceptions on truth, explanation, beliefs and views about the world. The result shows that the mayor paradigm in building the Banda Aceh city area referred to the concept of the Prophet's development in Medina, and the Aceh Sultanates in building the area. Success in building the country and region are basically fully committed to carrying out and enforcing Islamic law in order to be strong and reside in the souls of the people. Therefore the mayor believes and is committed to continuing to build the city of Banda Aceh as a civil city model that is inseparable from building Islamic law in a consistent manner.
\end{abstract}

\section{Keywords :}

commitment; political communication; Mayor; Banda Aceh.

\section{Introduction}

The Mayor is the city government chosen through a democratic system that is carried out on the basis of direct, general, free, confidential, honest and fair principles to regulate and manage government affairs and the interests of the local community in accordance with their respective functions and authorities as stated in Indonesian government law and Aceh government law and other laws that are tied to development authority. Thus in the Law of the Government of Aceh related to Mayor's affairs including planning, utilization and supervision of spatial planning, development control planning, implementation of public order and public tranquility, provision of public facilities and infrastructure, health sector subscribers, education and potential allocation of human resources, tackling social problems, services in the fields of employment and employment, facilitating the development of cooperatives, small and medium enterprises, providing services for administrative population and investment. ${ }^{1}$

But the mayor's special authority in the implementation of development in the privileged area of Aceh, the Mayor has the authority to hold religious life in the form of Islamic Shari'a for his followers in Aceh while maintaining harmony among religious people, the Mayor has the authority to carry out Islamic life, then the authority to organize education quality and add local content material in accordance with Islamic law without ignoring the role of ulama in the Mayor's policy setting. In addition, the Mayor has the authority to administer Madrasah Islamic and Madrasah Tsanawiyah education, and the Mayor has the authority to regulate public ports and airports that have been regulated in the Law on Aceh government.

Likewise, formal authority based on Article 25 and 27 of the Republic of Indonesia Law No. 32 of 2004, the regional head has the duty, authority, and obligation to lead the implementation of regional government based on policies stipulated with the DPRD; submit a regional regulation plan; stipulate regional regulations that have been approved by the DPRD; compile and propose regional regulations on APBD to DPRD to be discussed and stipulated together; strive to carry

\footnotetext{
${ }^{1}$ Law of the Republic of Indonesia Number 11 of 2006 concerning Aceh Governmen
} 
out regional obligations; represent areas inside and outside of service and can appoint legal counsel to report in accordance with the laws and regulations and carry out other authority duties in accordance with the laws and regulations.

\section{Review of Literatures}

\subsection{Political Communication}

In the past few decades, the study of political communication has experienced rapid development, and that growth has taken place throughout the world. When viewed from a historical standpoint, political communication has been known in early studies of democratic discourses from Aristotle and Plato. In its development, modern political communication relies on multidisciplinary based on concepts in communication, political science, journalism, sociology, psychology, history, rhetoric, and others. These developments, made various contributions to the definition of political communication. To bring understanding to the definition of communication consisting of two words, namely the word communication and politics, the two words will be explained separately without reducing the philosophical meaning and purpose.

The terminology of communication comes from Latin, namely Communico, which means to divide, and Communis, which means building togetherness between two or more people. The word "Communication" can also be interpreted as 'notification' or 'exchange of thoughts'. Broadly speaking, in the communication process, there must be elements of similarity in meaning that an exchange of thoughts and understanding occurs between communicators and communicants. Then the communication process has the meaning of transferring information or messages from the sender of the message as a communicator to the recipient of the communicant. The process of communication aims to achieve mutual understanding between the two parties involved in the process itself. The large Indonesian dictionary defines communication as the sender and recipient of messages or news between two or more people so that the message in question can be understood.

Communication is one of the most important forms of human activity without days of communication. Every living thing needs communication because communication is a symbol of the existence of life in society. Viewed from this perspective, communication shows the existence of a relationship and interactions that occur between two or more people. These interactions occur because someone conveys messages in a certain form that is received by other parties who are the target so that more or less will influence the attitudes and behavior of the party in intent. Anyone as a member of the community does this continuously sometimes even unconsciously, including those who do not understand the meaning and concept of communication. Therefore, it is understandable that communication is an activity carried out by all members of the community, anytime and anywhere.

\subsection{Civil Society.}

Civil Society is formed from a combination of the words "Society" and Civil. The two words, together are breakfast words from Arabic that have been standardized into Indonesian vocabulary. Therefore, in order to easily understand this concept, it will be explained the second meaning of the word. In the large dictionary Indonesian language defines the word "Society" with the meaning "a number of people in the broadest sense and bound by the culture that they consider the same". However, the word community basically comes from Arabic, namely the root word consists of letters sha (ش), ra (J), and kaf (ك). From the root word is formed words like, shirk, sharikat, and shirkah-sharikah. The first word, according to the dictionary Al-Munawir means an ally, the second word has the meaning of union, association, association, group or group. While the third word according to the Al-Maurid dictionary, means Company, Corporation, Firm, Business, Partnership, and Association. In the Al-Munjid dictionary it is said that al-shari'at means mixed. 
In terms of terminology, according to M. Quraish Shihab's search for the verses of the Qur'an, it is concluded that society is a collection of many small or large individuals bound by units, customs, laws, and shared life. In the Koran there are several words that are used to show people or groups of people. Among other things: qawm, ummah, sha'b, and qabilah. Ali Nurdin added eight terms of society besides that, such as firqah, taifah, hibz, fauj, expressions beginning with abl, expressions beginning with alu, al-nas, and asbat. These terms, by the Qur'an, are characterized by certain characteristics, such as al-Mala'al-mustakbirun, al-mustadh'alfun, al-muslimum, al-mu'minun, almushrikun, abl al kitab, and others- other. Quraysh Shihab and Dewam Rahardjo concluded that from the many terms of society used in the Qur'an, the word ummah which had been Indonesian became a people, closer to the understanding of the community.

The word civil, rooted in the word masdar (noun) of a series of letters dal (د), ya (ي), and nun (ن) of fi'il madi (verb) dana (د) (د) the word derives in the form word dain (take profit) and din (religion, submission, and submission). According to Harun Nasution and Nurcholis Madjid, they agreed to be in line with religion, law or law. In Arabic, the word also means mastering, subduing, obedient, debt, repayment and habit. Din is a bond that humans must hold and obey. Thus between the two meanings of this pattern (debt and religion) there is a close relationship. Then religion is essentially a responsibility that must be fulfilled by humanity in the form of its dedication to the Almighty creator. Apart from that, the derivation of the word also becomes the word Medina as an edible meal which is a change from the word madyan in the Qur'an called the city where the prophet Syu'aib lives. From the words of Madam and Madinah through the adjustment of the phoneme, the word civil is formed as the ratio of the word Medina, which is the ideal city built by the Prophet Muhammad. Thus, it can be said essentially that civil life is characterized by the supremacy of the law in the life and order of society

\section{Research Methods}

The paradigm of this study is the paradigm of constructivism, where the paradigm of constructivism begins with the fundamental question of how people in a place or location construct reality. This paradigm discusses their perceptions. Truth, explanation, beliefs and views about the world. Besides the consequences of the construction for their behavior and other people who interact with them are also examined. ${ }^{2}$

Guba and Lincoln explain, constructivism begins with the idea that humans have natural, physical differences and thus must be studied differently. This is because every human being has developed the capacity to interpret and construct reality. Constructivism is often referred to as a social process. Guba and Lincoln also explained that paradigms can be defined as a set of basic beliefs related to the main principles. A paradigm for adherents will represent a world view, which defines the nature of the world the place or position of the individual in it and the possible distance between the world and its parts.

Paradigm as a way of looking, can be contrary to one another or difficult to meet, because it has assumptions and explanations about its own social reality that is difficult to compare and assess one by one. Denzim and Lincoln, judging that the paradigm has 3 elements or assumptions, namely epistemology, anthology and methodology that can make a fundamental difference between these paradigms.

\section{Discussion}

Commitment of political communication in the mayor of Banda Aceh wants to build the community of the city of Banda Aceh as a model of the city. This political communication

2 Patton 2002, P. 96 
commitment arises from the determination of geopolitical analysis, the natural conditions of the region, the regional development policies of the Aceh province and the vision of national development. The strong desire of the mayor in building the community of the city of Banda Aceh as a civil model refers to the concept of the development of the Prophet in Medina, and the Aceh sultans in building the region. Success and success in building the country and region are basically fully committed to carrying out and enforcing Islamic law in order to be strong and reside in the souls of the people. ${ }^{3}$ Therefore the mayor is confident and committed to continuing to build the city of Banda Aceh as a model of a civil city that cannot be separated from building Islamic law. Then the political communication commitment was reformulated with the regional stakeholders of the city of Banda Aceh in a deliberate medium-term development plan deliberation to be able to become a shared vision and mission in building the community of Banda Aceh in the future.

Vision and mission are political messages that are conveyed and offered by the mayor to the stakeholders of the city of Banda Aceh to be understood in conference so that stakeholders in the city of Banda Aceh understand and provide support to the mayor in carrying out their duties, obligations and authorities in building the area in accordance with the commitment political communication of the mayor of Banda Aceh, so that the development vision and mission that has been determined can run in accordance with the common goals and expectations that can reflect the factual conditions of the region. The goal is none other so that the regional vision which is a picture of idealism about the future situation that contains the ideals and images that want to be realized is able to look far ahead about where and how the government brings and works to continue to exist, be consistent, anticipatory, innovative and productive. Thus, the defined development vision can bring enlightenment and motivation to all existing officials to constantly improve performance in order to realize this vision.

The established development vision needs to be embedded in each government organizational structure so that it becomes a shared vision, which in turn is able to direct and mobilize all available resources. Vision is a description of how the organization will appear when the organization successfully implements its strategy and reaches its full potential. A good vision according to Bryson that was elaborated from the opinions of Kouzes and Posner, presented inspirational features. Focusing on a better future, encouraging hopes and dreams, being attracted to common values, expressing positive results, suppressing the strength of a united group, using words, imagination and word metaphor, and communicating enthusiasm and joy that lights up this While in the same context, Efendi formulated that a vision should reflect what an institution wants to achieve, be able to provide clear direction and strategic focus, be able to become an adhesive and unite various strategic ideas contained in an institution and have an orientation towards the future, so all ranks must play a role in defining and shaping the future of their organization and being able to grow the commitment of all levels in the institutional environment, finally being able to guarantee the continuity of organizational leadership. ${ }^{4}$

Vision is also an ideal situation or condition to be achieved for the future, its nature gives input and direction and conditions in the future. Vision is also a dream or hope for the future that you want to manifest in reality. Determination of the vision for the future is the aspirations of the people combined with the results of the development consultations from the elements of government and the community, the representatives of the people of the city of Banda Aceh and other stakeholders.

In establishing the vision of the development of the city of Banda Aceh in accordance with the commitment of the political communication of the mayor delivered during the political

\footnotetext{
${ }^{3}$ Tun Dr. Mahathir Mohammad in the International Seminar held by the Harian Umum Waspada, Monday (07/182016) in Medan, North Sumatra. Jw Mariott Hotel

${ }^{4}$ Mawardy Nurdin. Strategi Membangun Kota Banda Aceh Berbasis Kompetensi, (Jakarta: Indomedia 2011), P. 158
} 
campaign there needs to be accommodation in line with the national medium-term development plan, the provincial development plan, and the long-term plan of the city of Banda Aceh. and intimacy in achieving the development goals of the city of Banda Aceh.

Judging from the 2015-2019 national development vision during the presidential period, Joko Widodo and Muhammad Jusuf Kala's vision of development is the realization of "Sovereign, Independent Indonesia, and a Basic Personality of Mutual Cooperation." To realize this vision it is pursued with 7 development missions namely : (1). Realizing national security that is able to maintain regional sovereignty, manage economic independence by practicing maritime resources, and reflect the personality of Indonesia as an archipelagic country. (2). Realizing an advanced, balanced and democratic society based on the rule of law. (3) Realizing free and active foreign policy and strengthening identity as a maritime. (4). Realizing the quality of life of Indonesian people who are high, advanced and prosperous. (5). Realizing a competitive nation. (6). Realizing Indonesia to be a maritime country that is independent, advanced, strong and based on national interests. (7). Creating a community that has a personality in culture.

Meanwhile, the Aceh provincial government in the regional mid-term development plan for 2012-2017 establishes a vision of development, namely "Aceh with dignity, prosperity, justice, and independence based on the Law on Aceh Governance as Mou Helsingki's Form". The stated vision means: Being dignified: is the creation of conditions of the people of Aceh who have high civilization, noble character, intelligent, broad-minded, law-abiding, healthy according to living standards and the realization of the Aceh government that is capable of carrying out its special and special authority. Prosperous, is the fulfillment of the life needs of people who are both material and spiritual who are balanced between the life of the world and the hereafter. Fairly, is the realization of a just, equitable, participatory and proportional development in accordance with the potential and superiority of the region based on the principle of benefit for the life of the community. Mandiri, is the realization of society and government that are able to fulfill their own basic needs by utilizing the potential of natural resources, human resources and other resources effectively, efficiently and sustainably.

In realizing the vision of Aceh, it was pursued through the five Aceh development missions, namely: (1). Improving the trustworthy governance of Aceh through the implementation and completion of implementing regulations for the UUPA in order to realize a dignified Aceh. (2). Strengthening the relationship between Aceh Government and all stakeholders in order to consolidate peace. (3). Applying the Dinul Islam and Acehnese civilization in all aspects of people's lives. (4). Improve the quality of human resources (HR). (5). Realizing proportional, integrated and sustainable Aceh development. (6). Building a strong, just and advanced Aceh economy by increasing product value added and optimizing the use of natural resources. In the RPJPD, the Banda Aceh City Development Vision was established "The Realization of Banda Aceh as a City of Tamaddun, Modern and Islamic" In the next 20 years the city of Banda Aceh is expected to become a city with high civilization, mastering and utilizing science and technology for the benefit and community welfare based on local wisdom and Islamic values. ${ }^{5}$

Based on this description, the mayor of Banda Aceh set a vision in building the mid-term city of Banda Aceh or the five-year future of the city of Banda Aceh carefully and strategically, based on an analysis of the geopolitical conditions of the Banda Aceh city, natural conditions and conditions of natural resources, as well as current issues, where the vision of the city has been outlined in the strategic plan of the city of Banda Aceh through Aceh Qanun No. 12 of 2013 concerning the 2012-2017 Aceh medium-term development plan. "Banda Aceh is the city model of civil."

Banda Aceh civil model is the political message of the mayor which has been formulated into a common vision and mission that has been agreed upon with the community and

\footnotetext{
${ }^{5}$ Documentation, Mid-Term Development Plan for Banda Aceh City for 2012-2017.
} 
stakeholders of the Banda Aceh city community in the implementation of medium-term development. The civil city in question is a city that has a faithful and noble population, maintains unity and unity, is tolerant of differences, obeys the law, and has a wide public space. Besides that the community participates in the implementation of development, is inclusive, is able to work together to achieve the common goals that are aspired. This situation is expected to give birth to the citizens of Banda Aceh who have a friendly, obedient, peaceful and prosperous identity, high self-esteem, cultured, and civilized.

Efforts to realize the vision of building the city of Banda Aceh as a model city, the city of Banda Aceh launched it into a desire, determination and strong shared commitment to the 7 missions, in the context of implementing governance and development, namely:

First : Improving the Quality of Islamic Shari'a Practice in Kaffah

Second : Strengthening Good Governance

Third : Strengthening the Democratic Economy

Fourth : Growing a Society that is Specific, Healthy and Prosperous, Mastering Various Sciences, Technology, Art and Culture

Fifth : Continuing Islamic Tourism Infrastructure Development

Sixth : Increasing Women's Participation in the Public Sphere and Child Protection.

Seventh : Increasing the Role of Young Generation as a Power of City Development.

To achieve the vision and mission of Banda Aceh City Principles and values need to be developed. Principally that needs to be developed. (1). The principle of democracy is to uphold freedom of expression in people's lives. (2). The principle of participation gives space for every citizen to have the same voice in making decisions, both directly and through the intermediation of legitimate institutions that represent their interests. (3). The principle of transparency creates a flow of information that is open to the public so that the public can understand the programs and activities carried out by the government. (4). Transparency is built on the basis of freedom of information. Processes, institutions and information that can be directly received by those who need information must be understood and can be monitored. (5). The principle of accountability, decision makers in government, the private sector and society (civil society) is responsible to institutions and stakeholders (stakeholders) and the community. (6). The principle of decentralization, the surrender of part of the authority of the city government to the government under it.

While the values that develop in the community of the city of Banda Aceh are very valuable capital in facing future challenges. These main values are the operational foundation that can stimulate stakeholders to achieve their vision and mission. The main values in question are:

a. Devotion: the values of the faith of mankind / servants of God to the Creator. In more complete manner, devotion is to carry out all obligations, stay away from all prohibitions and syubhat (vague cases), then carry out sunnah (mandub) cases, and stay away from makrub (hated) cases;

b. Justice: the attitude and actions of someone who treats other people according to their functions, roles, and responsibilities and by paying attention to the rights and obligations of the community;

c. Professionalism: skilled, reliable and responsible and full of dedication in carrying out his profession;

d. Honesty: a value where attitude and speech are in accordance with the actual situation and actions, preaching the truth without being replaced, changed, reduced or added. This has implications for policy making so that implementation is in accordance with the initial ideals when the policy was determined, socialized and explained as it is;

e. Integrity: a personality based on the elements of honesty, courage, wisdom, and accountability that give rise to trust and respect; 
f. Responsibility: willingness to bear something, that is if it is wrong to correct it or dare to be prosecuted or prosecuted;

g. Collaboration: commitment between members of the organization to support each other, avoiding sectorial egos that prioritize the part of their own organization; and

h. Sustainable: the development carried out does not only meet current needs but also does not sacrifice the fulfillment of the needs of future generations. ${ }^{6}$

With full commitment to maintain continuity in the process of implementing the regional development of the city of Banda Aceh, the mayor approached political communication between government agencies, non-ministries and regions in technical development coordination, coordinated by the administration of government affairs in the field of development planning. Done in the planning, implementation, control and evaluation stages of regional development. Regional development planning is outlined in regional long-term development plans, regional midterm plans, and, regional work plans, in accordance with the conditions and needs for regional development that are synergized based on national long-term development plans and regional long-term development plans and medium development plans. To maintain the continuity of the implementation of regional development and also become a guideline for regional work units in developing strategic plans and government work plans in building the community of Banda Aceh as a civil model.

\section{Conclusion}

Commitment of political communication in the mayor of Banda Aceh wants to build the community of the city of Banda Aceh as a model of the city. This political commitment arises from the results of the geopolitical analysis, the natural conditions of the region, the Aceh provincial regional development policy and the national development vision, and the strong desire of the mayor himself. The mayor paradigm in building the Banda Aceh city area referred to the concept of the Prophet's development in Medina, and the Aceh Sultanates in building the area. Success in building the country and region are basically fully committed to carrying out and enforcing Islamic law in order to be strong and reside in the souls of the people. Therefore the mayor believes and is committed to continuing to build the city of Banda Aceh as a civil city model that is inseparable from building Islamic law in a consistent manner.

\section{References}

A. Rani Usman, Sejarah Peradaban Aceh Jakarta: Yayasan Obor Indonesia, 2003

Abd Muin Salim, "Elaborasi Bahasa Politik Islam Dalam Alquran" Al-Huda; Jurnal Kajian Ilmu-Ilmu Islam, Jakarta: vol, 1 no. 2, 2002

Abdul Gani Isa, Formalisasi Syariat Islam di Aceh Pendekatan Adat, Budaya dan Hukum Banda Aceh: Yayasan Pena 2013

Ali Nurdin, Qur'anic Society : Menelusuri Konsep Masyarakat Ideal Dalam Al-Quran Jakarta: Erlangga, 2006

Alo Liliweri, Sosiologi Dan Komunikasi Organisasi Jakarta: Bumi Aksara, 2014

Anang Anas Azhar, Pencitraan Politik Elektoral Kajian Politik Segitiga PAN Dalam Merebut Simpati Masyarakat Yogyakarta:Atap Buku 2017

Antoni, Riubnya Persimpangan itu Profil dan Pemikiran Para Penggegas Kajian Ilmu Komunikasi, print 1 Solo: Tiga Serangkai 2004

Anwar Ibrahim Masyarakat Madani: Satu Tinjanan Awal (Kuala Lumpur: Malaysian Development Strategy Institute, 1998

${ }^{6}$ Documentation for the 2012-2017 Mid-Term Development Plan for the City of Banda Aceh 
Anwar Ibrahim, Islam Dan Pembentukan Masyarakat Madani Dalam Aswab Mahasin, (ed), Ruh Islam Dalam Budaya Bangsa: Wacana Antar Agama Dan Bangsa (Jakarta: Yayasan Festival Istiqlal, 1996,

Aprillia Theresia at el. Pembangunan Berbasis Masyarakat Bandung: Alfabeta, 2015

Ardial, Paradigma Dan Model Penelitian Komunikasi Cet.1 Jakarta: Bumi Aksara, 2014

Badan Pusat Stastistik Kota Banda Aceh Kota Banda Aceh Dalam Angka 2017.

Badan Pusat Stastistik Kota Banda Aceh, Master File Desa Kota Banda Aceh 2017

Deddy Mulyana, Komunikasi Politik Politik Komunikasi Membedab Visi Dan Gaya Komunikasi Praktisi Politik. Cet 1 Bandung: PT Remaja Rosdakarya, 2013

Dedi Mulyana, Komunikasi Efektif: Suatu Pendekatan Lintas Budaya, Bandung Remaja Rosdakarya, 2004

Departeman Pendidikan Dan Kebudayaan, Kamus Besar Babasa Indonesia, Jakarta: Balai Pustaka, 1989

Departemen Pendidikan dan Kebudayaan RI, Kamus Besar Bahasa Indonesia, Jakarta Balai Pustaka, 2008

Dirgo D. Purbo, Indonesia Keluar Dari Opec Demi Geopolitik "Energy Security" in journal Intelijen Dan Kontra Intelijen, vol. IV, No. 23, June 2008,

Dokumentasi Analisis Kondisi Kota Banda Aceh Rencana Pembangun Jangka Menengah Kota Banda Aceh Tahun 2012-2017.

Dokumentasi Rencana Akbir Rencana Strategis Satuan Perangkat Daerab Tabun 2012-2017 Dinas syariat Islam kota Banda Aceh, 2013

Dokumentasi Rencana Pembangunan Jangka Menengah Kota Banada Aceh Tahun 2012-2017

Dokumentasi, Analisis Kondisi Daerab Kota Banda Aceb Untuk Rencana Pembangunan Jangka Menengah Kota Banda Aceh Tahun 2012-2017, Dinas Pekerjaan Umum Kota Banda Aceh Tahun 2017

Dorpalen, The World Of General Haushofer. New York 1942.

Everett M. Rogers and F. Floyid Shoemaker, Communication Of Innovations, Terj. Abdillah Hanafi Surabaya: Usaha Nasional, 1981

Farid Hamid \& Heri Budianto, Ilmu Komunikasi: Sekarang Dan Tantangan Masa Depan Jakarta : Kencana Prenanda Media Group 2011

Fazlurrahman, Islam, Chicago-London: University Of Chicago Press, 1979

Fred N Kerlinger in Salim HS, Perkembangan Teori Dalam Ilmu Hukum, Jakarta Rajawali Press, 2012

Georoid O Tuahai. Critical Geopolitic. London 1996, Page 33.

Gun-Gun Heryanto, Komunikasi Politik Jakarta: Universitas Indonesia 2010

Hadari Nawawi and Mini Kartini, Penelitian Kualitatif Yokyakarta: Gajah Mada University Press, 1994

Indeks pembangunan manusia kota Banda Aceh 2015. Badan pusat stastistik kota Banda Aceh.

Indikator Kesejahteraan Masyarakat Kota Banda Aceh, Badan Pusat Stastistik Kota Banda Aceh 2016

Irsadi, Stategi Komunikasi Wilayatul Hisbah Dan Satuan Polisi Pamong Praja Dalam Pelaksanaan Syariat Islam Di Kabupaten Aceb Utara Tabun (Student Doctor: Uinsu 2017

Iskandar, Metodologi Penelitian Kualitatif Jakarta: Gaung Persada, 2009

Jhon Fiske, Pengantar Ilmu Komunikasi, Jakarta: PT. Remaja Grafindo Persada, 2012

Joko Subagyo, Metode Penelitian dalam Teori dan Praktek Jakarta: Rineka Cipta, 2001

Journal of Ketahanan Nasional, Geopolitik Dan Geostrategis Dalam Mewujudkan Integritas Negara Kesatuan Republik Indonesia, Accessed on 29 April 2018 jam 10:51 Vol 6 No.2 2001

Journal student Fisip Insyiah Volume 2, Nomor 3: Mei 2017

Maswadi Rauf \& Mappa Nasrun, Indonesia dan Komunikasi Politik, Jakarta: PT Gramedia Pustaka Utama, Anggota IKAPI, 1993

Material subject Komunikasi Pembangunan di Pascasarjana UINSU 2016. 
Maulida Ulfa, Politik Pembangunan Islam: Studi Terhadap Kota Madani Di Banda Aceh, Departemen Ilmu Politik Fakultas Ilmu Sosial Dan Ilmu Politik, Universitas Sumatera Utara Medan; Skripsi Tahun 2016

Mawardi Nurdin, Strategi Membangun Kota Banda Aceh Berbasis Kompetensi, Jakarta: Indomedia Global 2011

Micheal Rush \& Philip Althoff, Pengantar Sosiologi Politik, Jakarta: Pt Raja Grafindo Persada, 1997

Rahardjo Adisasmita, Pembangunan Kawasan dan Tata Ruang Yogyakarta: Graha Ilmu, 2010

Ramlan Surbakti, Ilmu Politik, print: 7 Jakarta: Kompas Gramedia 2010

Richard West and Lynn h. Tunner, Pengantar Teori Komunikasi Analisi Dan Aplikasi edisi 3 Jakarta: Salemba Humanika 2008

Ruhi Al Ba'albaki, Al Maurid, Kamus Arabi-Inkaliji Modern Arabic-English Dictionary Bairut: Dar AlIlm Li Al-Malayin, 1995

Ryan Yudhi Murianto, Strategi Kebijakan Pemerintah Kota Banda Acehdalam Mewnjudkan Masyarakat Madani, Fakultas Ilmu Sosial Dan Ilmu Politik Universitas Syiah Kuala Darussalam Banda Aceh, : Skripsi Tahun 2016

S Toto Pandoyo, Wawasan Nusantara Dan Implementasinya Dalam Uud 1945 Serta Pembangunan Nasional, Jakarta: Pt Bina Aksara 1985

S. Djuarsa Sendjaja, Materi Pokok Teori Komunikasi, print. 1, Jakarta: Universitas Terbuka, 1994

Sanusi, Teknik Komunikasi Pemerintah Dalam Membangun Masyarakat Madani di Kota Langsa, Program Pascasarjana Intitut Agama Islam Negeri Sumatera Utara Medan; Thesis 2011.

Saodah Wok, Teori-Teori Komunikasi, print. 1 Kuala Lumpu: Cergas SDN BHD, 2004

Simangungsong, Bonar, Sinuraya, Daulat, Negara, Demokrasi Dan Berpolitik Yang Profesional, Jakarta: Perpustakaan Nasional : Data Katalog Dalam Terbitan 2004

Sofyan Ibrahim. At el. Toleransi dan Kiprah Perempuan dalam Penerapan Syari'at Islam Banda Aceh, Dinas Syariat Islam Aceh 2009

Suharsimi Arikunto, Prosedur Penelitian, Jakarta: Rineka Cipta, 1999 